\title{
Willingness to Defend Latvia: Suffering from Disillusionment, Distrust and Individual Preferences and Abilities
}

\author{
Aleksandra Palkova (ORCID: 0000-0003-1144-9674),
} Rīga Stradiňš University and Latvian Institute of International Affairs https://doi.org/10.25143/willingness_to_defend_2021_ISBN_9789934563997_47-57

There is a significant number of existing polling and research on willingness of the Latvian population to defend its own country. The polling done for this research does not demonstrate significant deviations from the classical trends. The Latvian population traditionally has been prone to support its country against external enmities after regaining independence. The country of Latvia is being held dear, while criticism of the ruling political parties, politicians, the overall development of the state of Latvia has been high with clear signs of disappointment. Complicated relationships with neighbouring countries, in particular the Russian Federation, also increase the equivocal outlook among the Latvian population.

This chapter will deal with the trends in willingness of the population of the country to defend Latvia. It will provide three central explanations of what has been influencing and shaping the attitudes of the Latvian population and what is influencing them now. The three aspects to reckon with are: the attitudes towards Latvia's political and economic development over the last thirty years; the relationship with the Russian Federation (and Belarus); and the psychological and physical factors required for active actual defence. The chapter will argue that there is a significant disappointment and confusion among the Latvian population that prevents it from being stronger supporters of defending Latvia. The chapter will build on the polling data gathered for this research to demonstrate tendencies and make conclusions. 


\section{Attitudes towards Latvia's political and economic development}

Since Latvia regained independence, the willingness to defend the country among the Latvian population has had the tendency to decrease. The momentum of regaining independence, popular resistance against the Soviet Union and hopes for brighter future in the re-established nation state influenced the spirit of people. The uplifting feelings associated with the new state after the Soviet Union collapsed were visible through the Latvian society. Defending the state against external enemies was especially outspoken among the Latvian speaking part of the population. Poverty and living standard discrepancies between the Soviet Union and Western countries raised hopes for rapidly improving life as Latvia would tilt towards the West.

The political, economic, and social transformation of the 1990s did not result in increased welfare for the masses. This together with continuous political scandals facilitated disappointment among the Latvian population. Lengthy inability to improve the living standards for most of the population in combination with widespread corruption, criminality, highly negative opinions in mass media, with lack of perspective on individual level can be regarded as reasons for disappointment and consequently - decreasing patriotism and willingness to defend the country. Disappointment in the state and its political leadership, and country's slow economic development continued throughout the 2000s and into 2010s, especially when in the 2008-2009 economic crisis hit Latvia hard. As the Figure 1 of the chapter "Willingness to Defend the Baltic States in Quantitative Terms" research demonstrates, the willingness to defend Latvia has been gradually falling and in early 2010s reached the record lows of approximately 30 to 40 percent of the ones who are ready. The original disappointment about Latvia's post-Soviet economic and political development in the 1990s was gradually substituted with growing disillusionment after Latvia was struck by economic and financial crisis in 2008.

Data demonstrate that despite post-crisis economic development and worsening of the geopolitical situation in the region, the willingness to defend the country has not been rapidly increasing. In 2014, when the 
Ukrainian crisis emerged, the numbers of willingness to defend did increase, but the overall tendency of willingness to defend has kept falling instead. To explain the trend and the current situation with 2020 data, two factors must be analysed separately: economic disappointment and political disillusionment. The economic disappointment is related to the means and options that are available to most of the Latvian population both objectively and subjectively. The political disillusionment is tied to losing interest in political participation and sense of belonging to the nation state.

Economic disappointment is tied to the fact that despite being part of the European Union, the Eurozone, the Organisation for Economic Cooperation and Development (OECD) and many other multilateral economic organisations and institutions Latvia's socio-economic situation is still worse than that of the most other European Union member states. Gross domestic product (GDP) per capita of Latvia is not only at the levels of 69 percent of the EU average, ${ }^{1}$ but it is lower than that of the closest partners and historical friends Estonia and Lithuania. In reality, Latvia is the poorest country in the Baltic Sea region, besides Belarus and the Russian Federation. The fact that Latvia for 30 years already has been less developed economically in comparison to its closest neighbours does not facilitate the populations' willingness to defend the country.

Inequality levels in Latvia are significant, with GINI index still reaching 35.1 in $2018,{ }^{2}$ which does not help to improve the people's trust and support for the country or its society. Risk of poverty and social exclusion is high in Latvia, with 26 percent of population being subjected to risk of poverty. Although the number has been steadily decreasing over the years, the absolute number of poor people in 2019 was almost half a million. ${ }^{3}$ This is a sour situation if one takes into account that people with a sense of economic safety in their country are the backbone of those willing to defend the state by any means against any foreign enemy. Those who have material possessions, especially real estate property and lifestyle that they could lose in case of foreign attack and change of the government, are more willing to defend the status quo, including their own country.

Economic disappointment over three decades has become embedded in some parts of the Latvian state. In particular, in Eastern regions with continuously high structural unemployment rates, lack of perspective and an unbreakable poverty cycle over generations. ${ }^{4}$ Low levels of accumulated 
personal capital and economic perspectives lead to decreased willingness to defend the state. Sense of belonging and economic welfare cannot be separated. Willingness to defend the political system which has brought hardships and has not alleviated socio-economic burdens does not stimulate individual or popular support.

And this is tied to the second aspect - the political disillusionment among the Latvian population. Political disillusionment is a result of several factors. Most important of which is the continuous lack of strong nationwide political narrative. Latvia is a multi-ethnic society with freedom of religion and all the traditional civil liberties guaranteed to most of the population. Meanwhile, not only the ethnical, religious, cultural disunity has limited the development of a strong dominating yet inclusive narrative. It is also the long-term challenges with exclusion of certain parts of the population from the political process. Moreover, the complexity of the country's history, especially that of the World War II and the Soviet occupation, and decadeslong debates on historical memories did not result in generating one single, unifying message that would be acceptable to the majority of the population.

Due to the communist experiences, the post-Soviet transition, the EU accession and the constantly evolving political, social, cultural, and economic value system, the Latvian society is often confused and lacks a clear national narrative that would serve as the basis for patriotism in Latvia beyond the Latvian ethnical group. Attempts to build a national narrative are also traditionally tied to Latvia's past and history, neglecting modern day achievements and success stories. Such attempts at a national narrative ignore the natural diversity of every society and seek to exclude a wide range of smaller and bigger groups from the economic, social, legal, or political process. This exclusion over the past thirty years has diminished or prevented increasing the willingness especially of the ethnic non-Latvian population, i.e., predominantly Russian speakers, to defend the country. Ethnic non-Latvian population traditionally demonstrates low levels of readiness to defend the country.

Yet, it is not only the lack of an overarching and inclusive national narrative that would fit the socio-economic and culturally linguistic realities of modern Latvia. It is also about the political disillusionment stemming from the democratic political party system and its actors' behaviour. The political scene of Latvia for thirty years has been dominated by a high 
turnover of political parties. The political parties tend to not only adjust their names frequently, but also change their leadership, political positions, and allegiances. A visible and confusing problem for voters is the regular birth of new parties and their alliances before every elections and fundamental transformation of existing political parties even while they are represented in the parliament. Both eligible voters and general population tends to follow and support individual candidates and their failure to gain power or fulfil promises is seen with disappointment.

In addition - a large number of corruption scandals, as well as constantly high corruption perception in the country shows that the population distrusts the decision makers. Corruption scandals ranging from state capture to oligarchy and petty corruption have been a constant presence in the country. In addition to mismanagement of state funds, fraud cases, as well as inefficient public procurement procedures both on national level and municipal level, increases distrust in politicians and both elected and appointed officials. This has led to political disillusionment that is also clearly visible via the great number of protest voters at every election. A high number of people choosing to stay out of the political process, including elections, is also alarming and demonstrates that people do not see themselves as stakeholders in Latvia's political process, affecting also the willingness to defend the country.

Lastly, political disillusionment and economic disappointment is attributable to the low overall media-literacy level, ${ }^{5}$ as well as the limited understanding of democratic political process and free market economics among the general population. Too many people see themselves as being constantly played by the state, the decision makers, the entrepreneurs and the economic system itself. An abundance of political positions, media sources, as well as people-to-people connections within the country and with neighbouring countries have also an effect on willingness to defend Latvia. 


\section{Relationships with the Russian Federation (and Belarus)}

The relationship with Russia and Belarus is a significant aspect to fully understand the willingness of the population to defend Latvia. Both neighbouring countries exercise significant presence not only in Latvia's foreign and security policy, but also in Latvia's media space and society's mental space. Due to the Soviet past, there is a significant familiarity on the political, economic, and people-to-people levels. Diplomatic relations and economic cooperation between countries have been worsening over the past decade and currently have reached the level where Russia officially is seen as the main security threat of Latvia. ${ }^{6}$ Recently, also relations with Belarus have reached lows after the post-2020 election crisis. Meanwhile, for a significant number of Latvia's inhabitants, personal family and friendship connections with Belarus and Russia play a substantial role in perceiving or not perceiving either of these countries as a potential threat.

The case of defending Latvia against military threats from Russia is complex to explain. There is a greater number of factors that need to be considered. The first is that the number of ethnic Russians in Latvia is more than a quarter of population - more than 520 thousand. Out of those a little short of 137 thousand are non-citizens of the Republic of Latvia. ${ }^{7}$ The same logic and principles apply in the case of established long-term family, friendship, and business relations. Familiarity with people from the Russian Federation influences the way how the Latvian society, regardless of ethnicity, perceives the possible threats from the big neighbour.

Russian influence on the minds and hearts of the Latvian population is also actively exercised via Russian mass media, including entertainment programs. Due to widespread Russian language skills among the Latvian population and wide accessibility of programs originating from the Russian Federation, Russia may not be seen as aggressor or even a threat neither to Latvia, nor to the Western world in general. Russia may be perceived as misunderstood by the West and just exercising its legitimate national security interests. Such a perception is especially outspoken among the ethnically Russian population.

Belarus, on the other hand, has not been seen as an immediate security threat. Despite differences in geopolitical approaches and differences in political regimes, both countries have had constructive and improving 
economic relations, regular political consultations and even moments of friendly relations. In the minds of many Latvian people, Belarus was seen not only as a friendly country, but even as an example of a successfully governed state. The Latvian society has not learned to perceive Belarus as a potential security threat and defending against it is not seen as a concern. Even now, with Belarus openly leading hybrid warfare against Latvia, Lithuania and Poland, the population is not strongly positioned towards Belarus as a military security threat. Belarus like Russia should be considered from the point of view of active people-to-people relations. Common border regions and common economic projects are just the first examples. One should not forget almost 64 thousand ethnic Belarusians living in Latvia in $2021 .^{8}$ Approximately 28000 of those are citizens of the Republic of Latvia and approximately the same number are non-citizens of the Republic of Latvia.?

Among many other things, the high number of ethnically mixed marriages in Latvia contribute to the mutual understanding and decreasing willingness to defend the country against potential Russian (and Belarusian) invasion. The positive attitudes, predominantly among a significant part of Russian speakers in Latvia, towards Russia and its aggressive policies domestically and abroad are facilitated not only by the official channels but also by misinformation campaigns online. Very often people acquire their information about political processes from entertainment materials unrelated to news or credible information agencies. In combination with the distrust towards the national government and belief that "everyone lies", the Latvian population tends not to accept the neighbouring countries as an actual threat and their populations as enemies.

People don't want to accept that things they like could be wrong. And the same thing applies to Russia (and to reasonable extend Belarus) as the most immediate threats that Latvia would need to be defended against. Low readiness to defend the country is also tied to the fact that Latvia is part of the European Union and NATO. This situation facilitates understanding and belief that war is not imminent. Threats from China, North Korea or Middle Eastern countries like Iran are too distant for the Latvian population, therefore they do not cause a sense of anxiety and necessity to be prepared for actual warfare. The geopolitical situation in the region over the past thirty years has influenced the threat perception and the psychology of the Latvian population and consequently their willingness to defend the country. 


\section{Psychological and physical factors}

Individual's readiness to defend his or her country is an actual rational calculation based on arguments, fears, preferences, and mental predisposition. It is a complex structure of concerns, embedded beliefs and expected practical outcomes from action or inaction. Each individual in Latvia forms their position towards war and defence of their own country based on their own personal experiences with military and defence structures and products, including warfare itself.

Peoples' personal experiences with war may be an aspect influencing one's readiness to defend the country with military means. Highest numbers of people willing to defend Latvia were registered during the national movement that emerged during the protests among others against the war in Afghanistan. With many young people having personal experience with warfare and being part of the two-year mandatory military service in the Soviet army, the attitude towards the possibility of war and individual's participation in it was much more acceptable than nowadays. Several aspects are influencing this.

The first aspect is that more than one generation has grown up in Latvia without personal experiences of war and armed conflicts. In combination with video materials and real time stories available via news channels, documentaries, and even social media, people are acquiring a distaste towards engaging in a modern-day warfare. Unwillingness to be killed or severely crippled "as seen on TV", influences the way people are psychologically ready to defend ${ }^{10}$ Latvia.

The abolishing of conscription in Latvia in 2007 has also had a direct effect on people's readiness to defend their country via military means. People may see warfare as something very distant. They may see the war and defence as the responsibility solely of the professional army and not them personally. Additionally, a significant number of people in Latvia due to options to avoid military service when enrolment was still compulsory and because of the introduction of voluntary military enlistment have no practical experience with weapons, with military structures, with military equipment and modern war. Because of lack of military training, physical preparation and theoretical skills of warfare, the general population is ignorant towards war and does not think of itself as capable of surviving any armed conflict. 
Even the basic information on military infrastructure in the country or behaviour during a military conflict is unknown to most of the people in Latvia. With this emotional feeling of helplessness, Latvian population may be more prepared to physically leave the country rather than defend it.

Due to the aforementioned distrust in their own skills and physical abilities, people may tend to choose not to believe in a possibility of an armed conflict emerging where they could be asked to defend their country. Population will choose to believe that war is impossible rather than prepare themselves. Due to the inability to understand their role and place in the country in case of a military attack, individuals may choose to hope for the situation to never arrive instead of actively preparing themselves and their communities.

Finally, it is about the communities - friends, family, co-workers, and their willingness to defend the country. Defensive military actions are a mass event. The positioning and attitudes of the closest friends and Allies, as well as mass psychology is essential in convincing people to take action or to abstain from it. Lack of alternatives and threats to life, health, living standard, property and family are the reasons why people may opt for weapons. In case of missing immediate and unavoidable pressures, the choice may be alternatives to defending the country. Same is with the peerpressure - with existing peer-pressure people will chose to act one way or another. They may also choose to promise doing one thing or the other. This only means, that peacetime polling on people's willingness to defend the country may not accurately present their actual readiness.

\section{Conclusions}

The question if people are willing to defend Latvia is a complex one, that requires complex answers. The decreasing percentage of the population that is ready to defend the country can be explained by the overall development in and of Latvia within the past thirty years. The country has managed to achieve geopolitical and geo-economic stability and does not face immediate threats even from its most worrisome neighbours, especially Russia. Current low levels of readiness to defend Latvia that the population demonstrates should be considered as a natural outcome of the situation that the Latvian 
society has been living in. The readiness level to defend Latvia among the Latvian population is only around thirty percent due to several reasons: NATO membership and Euro-Atlantic partnerships as safety guarantees, biased views on Russia (and Belarus), low levels of skills and knowledge of how to act in case of military conflict, low levels of trust in the political system and political disillusionment, as well as high levels of economic disappointment within the Latvian society.

Too many Latvian people do not feel like they are shareholders in their own country. They do not see the country worth defending. And they don't see why they should be defending it against Russia, Belarus, or any other country. Hence, the country should think about its patriotism level and the possibility of deepening the bond with citizens via public diplomacy instruments such as open activities and public events. A good example is the "Latvian Song and Dance Festival", where individuals feel a sense of belonging to the country and share common values. That kind of impact on society could contribute to the growth of the patriotism level and the willingness to defend.

One of the core problems are that individuals don't know how to defend not only the country, but even themselves. Defence of the country has become something distant and most likely would be met with widespread panic and mass exodus. Consequently, engaging more people, both young and older, in military training, including via theoretical and informative programs on television and internet that the population can access at any time, would be a major step towards raising people's awareness and, accordingly - the willingness to defend Latvia.

\section{ENDNOTES}

${ }^{1}$ Eurostat. GDP per capita, consumption per capita and price level indices, June 21, 2021, https:// ec.europa.eu/eurostat/statistics-explained/index.php?title=GDP_per_capita,_consumption_ per_capita_and_price_level_indices.

2 World Bank data. Gini index (World Bank estimate) - Latvia. https://data.worldbank.org/indicator/SI.POV.GINI?locations=LV.

${ }^{3}$ National Statistical System of Latvia. People at risk of poverty and social exclusion in Latvia in 2019, in Latvian. January 14, 2021, https://www.csb.gov.lv/en/statistics/statistics-by-theme/ social-conditions/poverty/search-in-theme/433-people-risk-poverty-and-social-exclusion.

${ }^{4}$ National Statistical System of Latvia. Share of unemployed persons among economically active population aged 15-74 in regions, cities, municipalities, towns, rural territories (based on the boundaries in force at the beginning of 2021), neighbourhoods and densely populated areas 
(experimental statistics) 2011 - 2020, https://data.stat.gov.lv/pxweb/en/OSP_PUB/START EMP_NBBA_NBB1/RIG090/.

${ }^{5}$ Anda Rožukalne, Ilva Skulte, and Alnis Stakle. Media education in the common interest: Public perceptions of media literacy policy in Latvia. Central European Journal of Communication (2020), 208-210.

${ }^{6}$ Latvijas Sabiedriskie Mediji. Stoltenbergs un Kariņš uzskata - Krievija arvien ir drauds Latvijai un NATO [Stoltenberg and Kariņš believe that Russia is still a threat to Latvia and NATO]. November 13, 2020. https://www.lsm.lv/raksts/zinas/arzemes/stoltenbergs-un-karins-uzskata--krievija-arvien-ir-drauds-latvijai-un-nato.a381617/.

7 Pilsonības un migrācijas lietu pārvalde. Latvijas iedzīvotāju sadalījums pēc nacionālā sastāva un valstiskās piederības [Distribution of the Latvian population by national composition and nationality]. January 14, 2021. https://www.pmlp.gov.lv/lv/media/2885/download.

${ }^{8}$ Ibid.

9 Ibid.

${ }^{10}$ J. David Slocum. "Cinema and the Civilizing Process: Rethinking Violence in the World War II Combat Film." Cinema Journal 44, no. 3 (2005): 43. 